\title{
TWO IMPORTANT PORCELAIN PIECES FROM THE YONGLE PERIOD
}

A group of very fine Ming porcelain in the collection of the Princessehof Museum was produced in the early 15 th century. ${ }^{1}$ This article will focus on two of these pieces, recount their individual biographies and relate them to the life of the Yongle emperor (1403-1424) (fig. 2). ${ }^{2}$ The vase and the dish illustrate one of the most brilliant reigns in Chinese history.

They are not just rare, beautiful and priceless, but are key works related to the dramatic life of a ruler whose reign was clouded by trauma. Many of his political and religious strategies as an emperor can be traced to his own personal experiences of guilt and fear.

\section{The Yongle emperor}

Zhu Di, the future Yongle emperor, was born in 1360; as the fourth of 29 sons of the founder of the Ming dynasty, Zhu Yuanzhang - the Hongwu emperor (1368-1398). In 1370, he was granted the title of Prince of Yan, a fiefdom comprising Beijing, the old capital of the Mongols. This was where he grew up.

In 1398, the Hongwu emperor died. He was succeeded by his eldest grandson, Zhu Yunwen - crowned as the Jianwen emperor (1398-1402) who was 16 years old, gentle, scholarly and indecisive. A deadly feud began between Zhu Di, commander of the important Northern region, and his nephew, the new Jianwen emperor. Zhu Di led a rebellion, and in 1402 marched his troops to Nanjing. The capital fell, and Zhu Di declared himself emperor, with the reign title of Yongle, meaning 'perpetual happiness'. In 1403, he therefore ascended the throne with a most propitious motto, but with what we would now call a personal trauma behind him. The question that haunted him was: What had happened to the Jianwen emperor? Not much is known, because Yongle, after his coup d'etat and the usurpation of the throne, tried to rewrite history. He not only physically eliminated all supporters of Jianwen, but erased all memories of them, to portray himself as the legitimate emperor of China.

But there were rumours. When Yongle's troops had entered Nanjing, the palace had caught fire, and a charred body was found in one of the burned-

Fig. 1

Large vase with dragon and lotus-scrolls, lingdezhen porcelain decorated in underglaze blue, h. $43.0 \mathrm{~cm}$., d. 33.0 cm., Ming dynasty, Yongle period (1403. 1424), Museum Princessehof Leeuwarden, NO 1109 down palace buildings. It may have been the body of the Jianwen emperor, but nobody could be sure. Jianwen was popularly believed to have fled the country - and Yongle must have lived in the constant fear of his nephew's return.

\section{The famous Princessehof Dragon Vase}

Keramiekmuseum Princessehof houses a large and famous dragon vase (fig. 1),

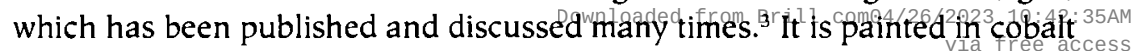


像帝皇文祖成

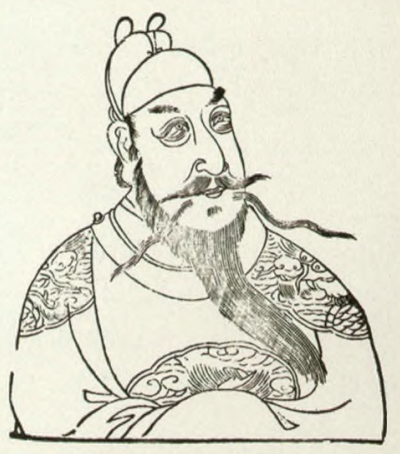

Fig. 2 (above) Woodblock print of the Yongle emperor. Source: Sancai tuhui (Illustrated collection of the Three Forces ), section renwu (persons), compiled by Wang Qi and Wang Siyi (1609).

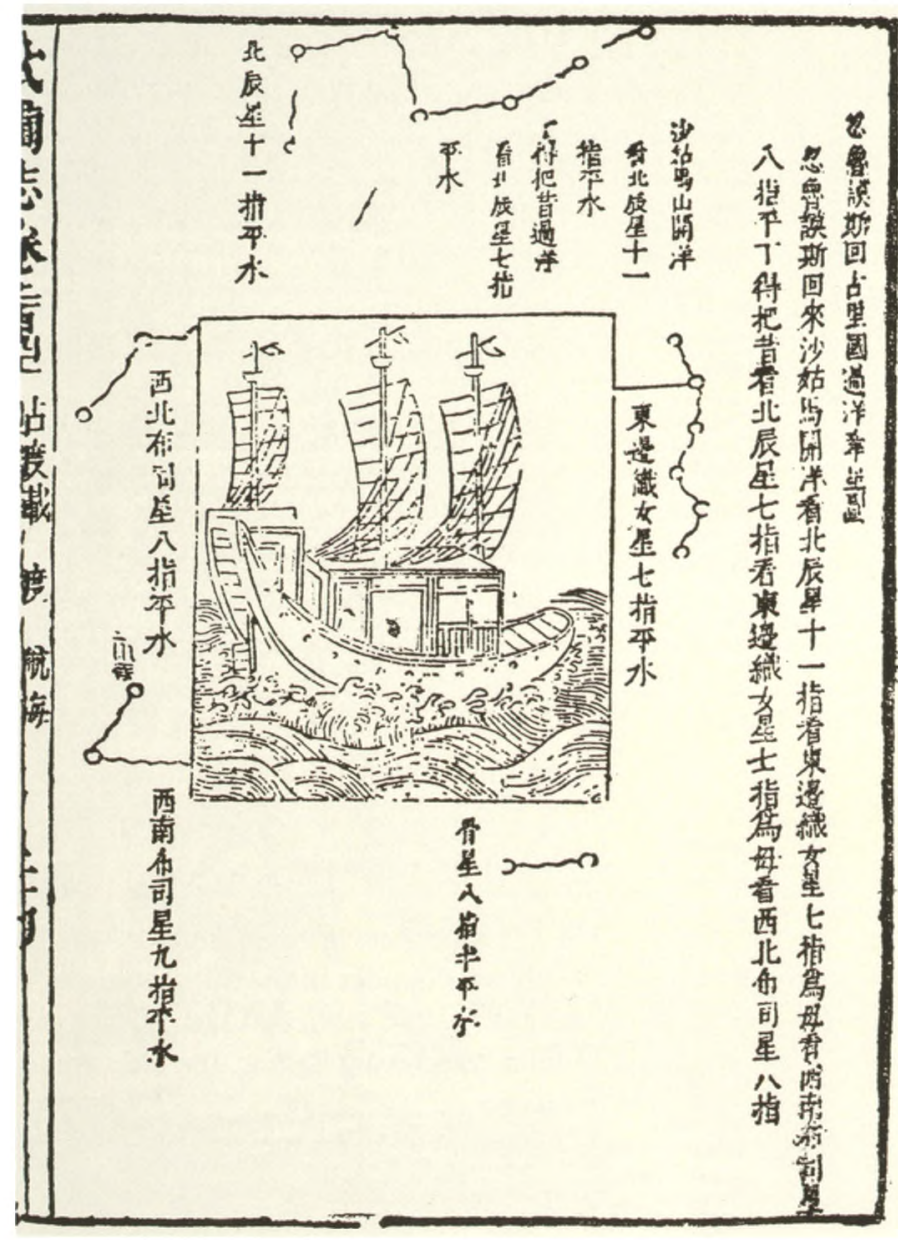

Fig. 3

Sea map, used by Zheng He. Woodblock print. Source: Zheng He hanghai tu (Seamaps of Zheng He), China, 1628. blue and shows a dragon, vibrant with energy, surrounded by lotus scrolls. It is dated in the reign of the Yongle emperor.

The vase was acquired by Nanne Ottema (1874-1955) in a small antiques shop in Rotterdam in 1935. The dealer provided Ottema with the information that the vase was found on the Sangir (Sangihe) Islands in Indonesia. This name refers to a group of 77 volcanic islands stretching north of Sulawesi in the direction of the Philippines. They were under Dutch control from 1677. How did this unusual and rare piece of porcelain, of which only four comparable pieces are known, arrive at such a distant and unlikely location?

\section{The Seven Sea Voyages of Admiral Zheng He}

In 1405, the emperor sent out his trusted admiral Zheng He (1371-1433), to command a gigantic fleet of ships on the legendary Seven Sea Voyages to the far corners of the known world (fig. 3). ${ }^{4}$

The Chinese had already been sailing to Southeast Asia, the Middle East, East Africa and Egypt since the Tang dynasty (618-907), but no officially sponsored tributary missions of this grandeur and size had ever been assembled before. 
By the start of the Ming dynasty, China had reached a peak of naval technology unsurpassed in the world at that time. For this reason, Yongle decided to commission these maritime expeditions; to impress foreign peoples with the power of the Ming dynasty and convince them of the glory and legitimacy of his own reign. On the orders of the Yongle emperor, the Nanjing shipyard built 2,000 vessels, called "treasure ships". They were large enough to hold 2,500 tons of cargo each; almost 140 metres long. Compared to these "treasure ships", La Santa Maria, the largest of the three ships of Christopher Columbus (1451-1506) with a length of about 18 metres, was tiny.

Between 1405 and 1433, Zheng He commanded seven sea voyages. Being a Muslim himself, he was able to facilitate their acceptance in many of the Muslim-controlled ports.

These voyages, comprising hundreds of ships with soldiers, diplomatic specialists, medical personnel, astronomers and scholars of foreign ways, particularly Islam, journeyed to Southeast Asia, including Champa (central Vietnam) and Siam (Thailand), and into the Southeast Asian archipelago: to Sumatra, Java and Aceh. They sailed to India and Sri Lanka, and on to the African east coast. On the last voyages they came up the Red Sea to Jidda, close to the holy cities of Mecca and Medina.

Trade in luxury goods was an important aspect of these extraordinary voyages undertaken by Zheng He. Porcelain and silk were the most prestigious diplomatic gifts. Several visits to the predominantly Islamic rulers of the Indonesian archipelago are recorded and diplomatic gifts were exchanged.

This was a hugely important mission in world history, comparable only to the voyage of Columbus almost 100 years later. To a psychologist, however, Yongle's missions might be interpreted as an obsessive search to find his nephew, the disappeared Jianwen emperor.

In the case of the Princessehof dragon vase, it is strange that the powerful dragon is depicted with three claws. The vase was made in the imperial kilns in Jingdezhen on the order of the emperor, but not for the Yongle emperor himself, which would have required a five-clawed dragon. A dragon with three claws, however, would have been an ideal diplomatic gift for a foreign ruler. The dragon vase now in the Princessehof collection is in all probability one of the diplomatic gifts carried during the Zheng He voyages.

\section{A large white glazed dish from the Princessehof collection}

The Princessehof museum has in its collection a large and beautiful white glazed dish. (figs. 4, 5,6). It is one of the most intriguing parts of the collection. With a diameter of $43.5 \mathrm{~cm}$., it is the largest known piece of this type. ${ }^{5}$ The dish was made in the Yongle period and may be connected with another of the many traumas that haunted the life of the Yongle emperor.

It appears that Yongle was not the son of the empress Ma, his father's primary wife. It was speculated that the actual mother of Zhu Di was one of the concubines of Zhu Yuanzhang, a girl of Korean or Mongolian origin. One of his first acts as an emperor in Nanjing, the first Ming capital, was to build a temple to commemorate his deceased parents; his father and his putative mother, the empress Ma. Great state offerings were planned for the occasion. To make it an event of high importance, the emperor sent for the 

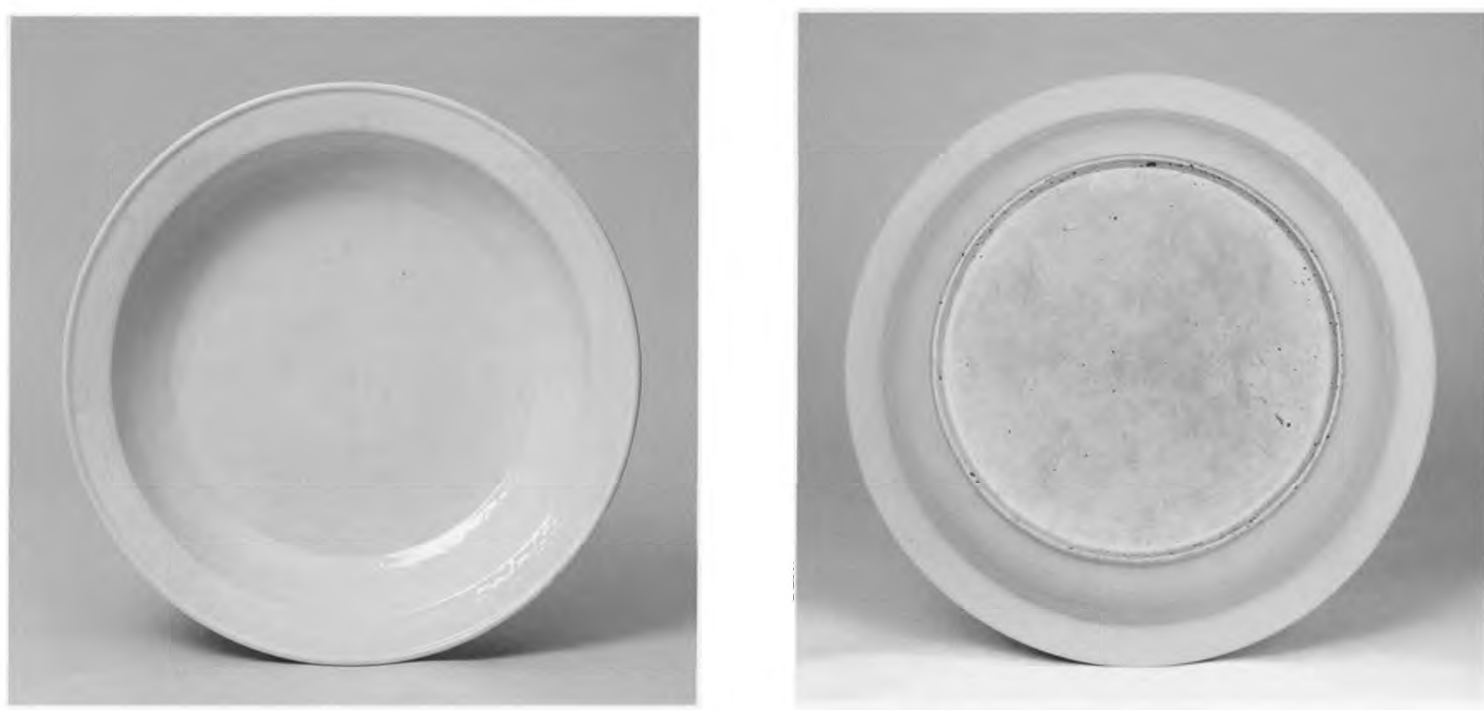

Figs. 4, 5, 6 (above and above right)

Large white glazed dish, lingdezhen porcelain with a tianbai glaze,

h. $8.0 \mathrm{~cm}$., d. $43.5 \mathrm{~cm}$., Ming dynasty, Yongle period (1403-1424).

Acquired with the help of the Vereniging Rembrandt, Prins Bernhard

Cultuurfonds and Aardewerk, Den Haag. Inv. No. OKS 1974-23

Fig. 7 (right)

Outline of the anhua decor

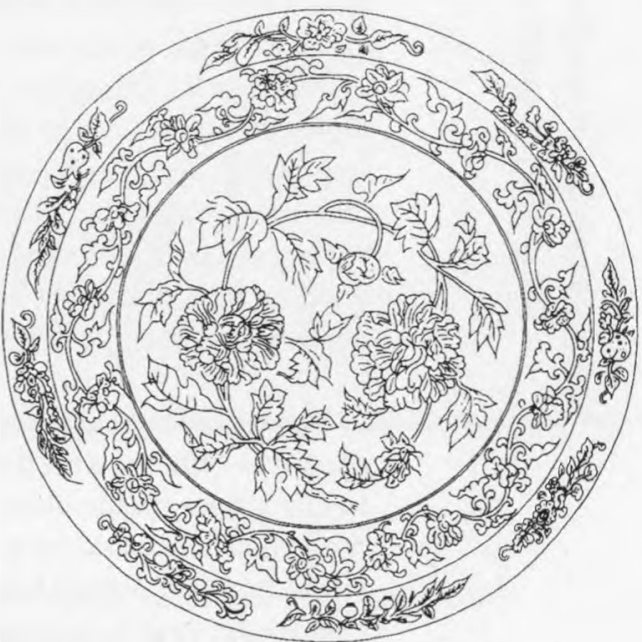

Fig. 8 (opposite page) Detail of the dish fig. 4 fifth Karmapa, the Tibetan lama Deshin Shegpa, known in China as Halima or Helima (1384-1415). This high ranking dignitary arrived at the capital in 1407 , riding on an elephant with an entourage of distinguished lamas around him, and he was received with great pomp and ceremony. In 1413, a group of important Tibetan lamas visited Nanjing again and missions and gifts were exchanged hereafter. ${ }^{6}$

The present dish is covered with a white, glossy glaze that is very smooth to the touch. A miracle unfolds when you are lucky enough to be able to hold the dish obliquely to the light: the mat glaze reveals minute bubbles, extremely small and dense, which reflect and scatter the light, thus giving an appearance of softness to the glaze. Moreover, in the right reflected light, a very subtle and beautifully incised decoration becomes just visible under the glaze; in

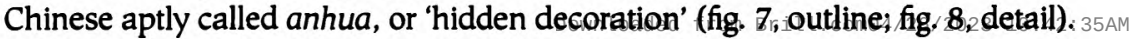



Designs made in this fashion were reserved for pieces used by the emperor himself or at the imperial court.

In the center of the dish, a single large branch with two full-blown peonies is depicted, surrounded in the cavetto with a continuous flower scroll. On the rim there is an incised design of eight flower and fruit sprays. It is this process of slowly and carefully revealing its beauty, which makes this dish so intriguing. ${ }^{7}$ It was only during the reign of Yongle that the famous glaze called tianbai, literally 'sweet white', was developed. It was called tianbai in China because it appears sugary. The Yongle 'sweet white' is considered the finest in quality. ${ }^{8}$ Chemical analysis shows that tianbai was almost entirely made of kaolin with no burned limestone. It therefore contains less calcium carbonate than other or earlier white wares. The reduction of calcium carbonate has the effect of making the glaze appear even whiter when fired at a high temperature. ${ }^{9}$

Why the emperor's obvious preference for the colour white, a white glaze? And what was this beautiful dish used for?

White in Chinese tradition is the colour of mourning. White cloth should be worn at funerals, and white glazed porcelain vessels would therefore be appropriate for offerings to the deceased ancestors. In Buddhist tradition, white represents purity and knowledge. It is associated with the transcendent buddhas Vairochana and Akshobya and vessels used for Buddhist offerings were normally white. The anhua design of the white Princessehof dish consists of flowers that were traditionally offered at Buddhist ceremonies. These qualities recall the events of 1407 and 1413, when the emperor invited high lamas from Tibet to conduct the offering ceremonies at the temple for his deceased parents. It is recorded that the Yongle emperor had large quantities of porcelain sacrificial vessels made at Jingdezhen for these occasions. The Princessehof dish, large, impeccably made at the imperial kilns in Jingdezhen, might well be one of the dishes ordered by the emperor for these specific events.

It seems that there are moments in the history of Chinese porcelain, when the biographies and personalities of the emperors themselves strongly influenced the ceramics made during their reign: their shapes, designs and function. These two important porcelain pieces in the Princessehof museum, the dragon vase and the white dish, embody personal facets of the Yongle emperor's life in a most beautiful ceramic form.

Dr. Eva Ströber is currently curator of Oriental ceramics at Keramiekmuseum Princessehof in Leeuwarden. Before coming to the Netherlands, she has worked at the Porcelain Collection Dresden, Germany, as curator for the collection of Oriental porcelain of Augustus the Strong. Her academic background is in Chinese studies, Oriental art history and comparative religion.

\section{Literature}

John M. Addis, Hung Wu and Yung Lo White, Transactions of the Oriental Ceramic Society 41 (1975-77), pp. 35-58.

Jessica Harrison-Hall, Ming Ceramics in the British Museum, British Museum Press, London, 2001. 
Christiaan J. A. Jörg, Oriental Porcelain in the Netherlands: Four Museum Collections, Groninger Museum, Groningen, 2003. [tent. cat.]

Regina Krahl and John Ayers, Chinese Ceramics in the Topkapi Saray Collection, Istanbul, Volume IV 625, Sotheby's, London, 1986.

Louise Levathes, When China ruled the Seas: The Treasure Fleet of the Dragon Throne, 1405-1433, Oxford University Press, Oxford, 1996.

John A. Pope, Chinese Porcelain from the Ardebil Shrine, Smithsonian Institution Freer Gallery of Art ,Washington, 1965.

Suolang Qujie, Reconciliation and Legitimization: The Fifth Karmmapa Deshion Shegpa's trip to Ming China (1406-1408), Master's thesis, University of British Columbia, Vancouver, 2012.

William Sargent, Treasure of Chinese Export Ceramics at the Peabody Essex Museum, Yale University Press, Salem, MA, 2012.

Rosemary Scott, 'Porcelains from the Reign of Perpetual Happiness', Transactions of the Oriental Ceramic Society 75 (2010-2011), pp. 27-38.

Urban Council Hongkong and Jingdezhen Museum of Ceramic History, Imperial Porcelain of the Yongle and Xuande Periods: Excavated from the Sites of the Ming Imperial Factory at Jingdezhen, Urban Council, Hongkong, 1989.

James Y. C. Watt and Denise Patry Leidy, Defining Yongle: Imperial Art in Early Fifteenth Century China, Metropolitan Museum of Art, New York, 2005.

Nigel Wood. Chinese Glazes: Their Origins, Chemistry and Recreation, A.C. Black, London, 1999.

\section{Notes}

1. Photo credits: Johan van der Veer, Princessehof Museum, Leeuwarden.

2. For a recent publication on Yongle and on art under his reign, see Watt and Patry Leidy 2005.

3. For a summary of research on this vase, see Jörg 2003: 66-7, no. 33.

4. For the missions of Zheng He, see Levathes 1996.

5. Six white glazed dishes are in the Ardebil collection, see Pope 1965: pls. 110-112. The Topkapi collection has seven, see Krahl and Ayers 1986: IV/625: 522.

The white dishes from the collection of John M. Adiss were given to the British Museum, see Harrison-Hall 2001: 102-3, nos: 3;6-3;10

6. For recent research, see Qujie 2012.

7. It should be mentioned here that the flower of the anhua design is also found as a motif painted in underglaze blue on a number of dishes in Chinese imperial collections as well as in the historical collections of the Middle East. Both types seem to have been produced at Jingdezhen, for the court and for export. For a recent summary, see Sargent 2012: 45-6, no. 1.

8. For a discussion on Yongle white wares, see Addis et al 1975-77: 35-58; and Scott 2010-2011: pp. 27-38.

9. Wood 1999: pp. 66-7.

For excavations of Yongle tianbai, see Urban Council Hongkong and Jingdezhen Museum of Ceramic History 1989: 88-128, nos. 3-23. 


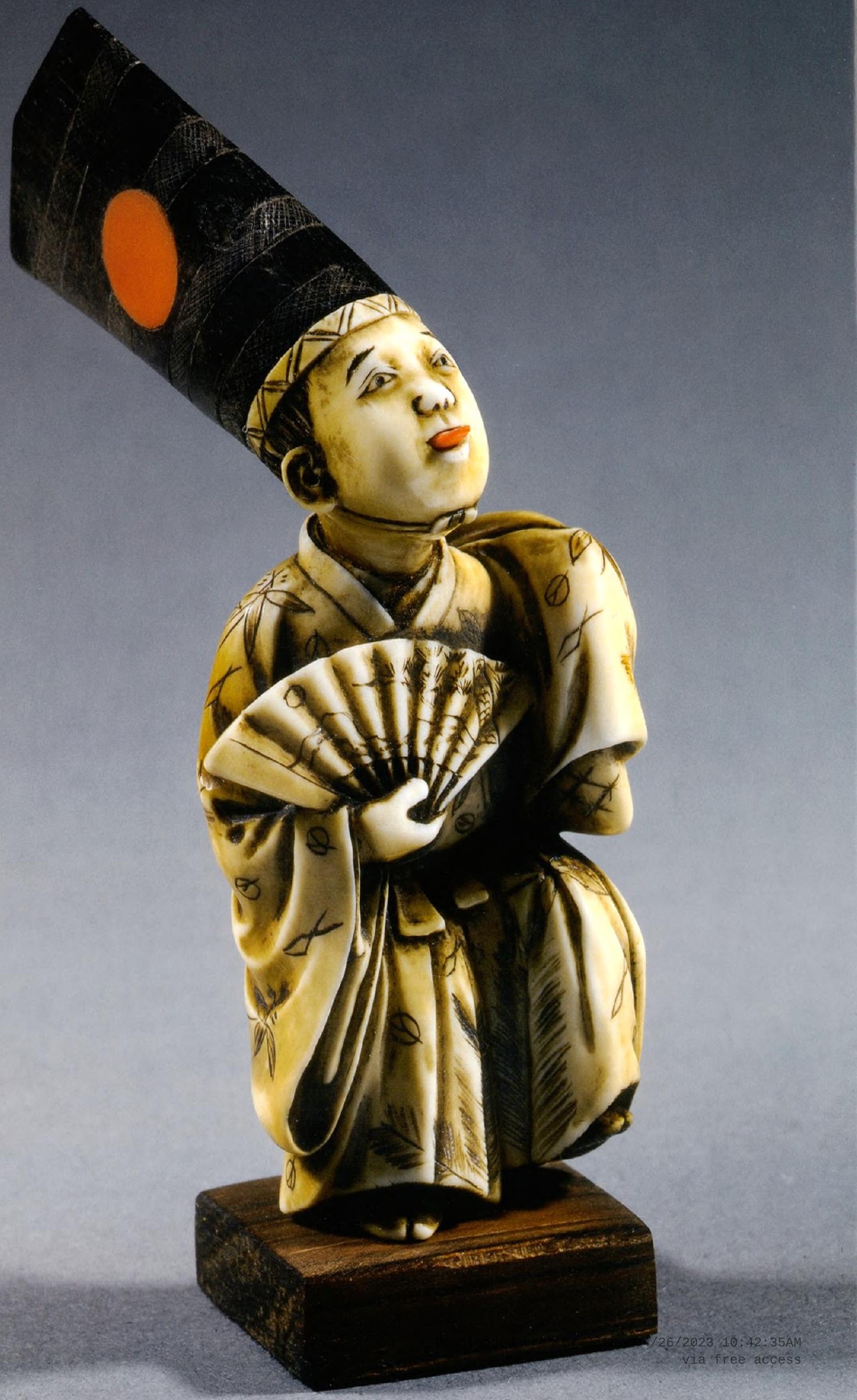

